\title{
KARAKTERISTIK MIKROKAPSUL MINYAK ATSIRI LENGKUAS DENGAN MALTODEKSTRIN SEBAGAI ENKAPSULAN
}

\author{
[Characteristics of Galangal Essential Oil Microencapsulation Using Maltodextrin Encapsulant]
}

\author{
Supriyadi* dan A. Sakha Rujita \\ Jurusan Teknologi Pangan dan Hasil Pertanian, Fakultas Teknologi Pertanian, Universitas Gadjah Mada, Yogyakarta
}

Diterima 31 Oktober 2013 / Disetujui 18 Desember 2013

\begin{abstract}
Research on encapsulation of galangal (Alpinia galanga) essential oil using maltodextrin as a coating substance was aimed to determine the ideal proportion between the essential oil and coating material to produce microcapsules, and to determine its characteristics. The ratio of galangal essential oil and maltodextrin studied were 1:8, 1:10, and 1:12. Emulsification was performed using Turrax homogenizer at 11.500 rpm for $2 \mathrm{~min}$. Microencapculation was performed by spray drying at inlet and outlet temperatures of 120 and $80^{\circ} \mathrm{C}$, respectively, and feed flow rate of $15 \mathrm{~mL} / \mathrm{min}$. The optimum conditions for microcapsules were determined based on the water content, aw value, surface- and entrapped-oil, and volatile compounds profile (total volatile and volatile composition) of the microcapsules. Microcapsules prepared by essential oil and maltodextrin at a ratio of 1:10 was found to have better characteristics. The microcapsules had a moisture content of $6.27 \%$, aw of 0.49 , surface oil of 1.22 and total volatile of $42.22 \%$. Methyl cinnamate, 1.8-cineole, $\alpha$-pinene and $\beta$-pinene were found as the main volatile constituents in both of essential oil and microcapsules. Methyl cinnamate was more stable than the other volatile compounds, even after encapsulation process.
\end{abstract}

Keywords: Alpinia galanga, encapsulation, essential oil, galangal, maltodextrin

\begin{abstract}
ABSTRAK
Enkapsulasi minyak atsiri lengkuas (Alpinia galanga) dengan menggunakan maltodekstrin sebagai bahan enkapsulan ditujukan untuk mengetahui proporsi yang ideal antara bahan enkapsulan dengan minyak atisiri untuk menghasilkan mikrokapsul; dan untuk mengetahui karakter mikrokapsul yang diperoleh. Variasi perbandingan minyak atsiri dan maltodekstrin yang dipelajari adalah 1:8, 1:10, dan 1:12. Pembentukan emulsi dilakukan dengan menggunakan Turrax homogenizer dengan kecepatan $11.500 \mathrm{rpm}$ selama 2 menit. Pembentukan mikrokapsul dilakukan dengan menggunakan pengering semprot (spray dryer) dengan suhu inlet dan oulet sebesar 120 dan $80^{\circ} \mathrm{C}$, kecepatan aliran bahan sebesar $15 \mathrm{~mL} / \mathrm{menit}$. Mikrokapsul dengan kondisi optimal ditentukan dari kadar air, nilai aw, minyak atsiri di permukaan (surface oil), minyak atsiri terperangkap (entrapped oil), total volatil, dan profil senyawa volatil. Mikrokapsul yang diperoleh dengan perbandingan minyak atsiri dan penyalut 1:10 menunjukkan kondisi penyiapan paling baik. Sifat mikrokapsul yang diperoleh mempunyai kadar air $6.27 \%$, aw sebesar 0.49 , minyak terperangkap dan volatil total masing-masing sebesar 1.22 dan $42.22 \%$. Senyawa metil sinamat, 1.8-sineol, $\alpha$-pinen dan $\beta$--pinen merupakan senyawa utama penyusun minyak atsiri dan mikrokapsul minyak atsiri lengkuas. Senyawa metil sinamat merupakan senyawa utama yang paling stabil dibandingkan ketiga senyawa lainnya.
\end{abstract}

Kata kunci: Alpinia galanga, enkapsulasi, minyak atsiri, lengkuas, maltodekstrin

\section{PENDAHULUAN}

Lengkuas (Alpinia galanga) merupakan salah satu spesies Zingiberaceae dan banyak dimanfaatkan sebagai penyedap makanan atau sebagai obat. Produksi lengkuas Indonesia selama tiga tahun dari tahun 2009-2011 relatif tetap sekitar 58.665 ton (BPS, 2012). Bagian tanaman lengkuas yang dapat digunakan sebagai penyedap makanan adalah bagian rimpangnya (Kaushik et al. 2011). Beberapa contoh makanan yang menggunakan rimpang lengkuas sebagai bahan penyedap adalah rendang, gudeg, rawon, dan sebagainya.

Pemanfaatan rimpang lengkuas sebagai bumbu masakan masih menggunakan rimpang segar atau bentuk kering. Syamsir (2011) mengatakan bahwa keuntungan dari rempah

*Penulis Korespondensi:

E-mail: suprif248@ugm.ac.id; Telp: 0274-589650 segar adalah memiliki flavour yang lebih lengkap dan segar. Akan tetapi, rempah bentuk segar memiliki umur simpan yang pendek, relatif lebih tinggi kandungan mikrobanya, dan konsistensi flavoumya sulit dipertahankan. Hal serupa juga terjadi pada penggunaan rempah bentuk kering yang ternyata juga belum dapat melindungi kehilangan senyawa flavour dari lengkuas selama penyimpanan.

Minyak atsiri merupakan komponen aroma yang bersifat volatil dan berbentuk cair yang biasanya didapatkan dari tanaman (Hamid et al. 2011). Minyak atsiri lengkuas banyak dimanfaatkan dalam berbagai bidang dan dapat digunakan sebagai anti mikrobia, baik bakteri maupun jamur (Yuharmen et al. 2002), untuk bahan farmasi, kuliner, dan kosmetik (Chudiwal et al. 2010). Meskipun banyak digunakan dalam berbagai bidang, minyak atsiri rentan terhadap suhu tinggi, oksidasi, sinar UV, dan kelembaban (Petrovic et al. 2010 dan Calvo et al. 2012) sehingga diperlukan solusi untuk mengatasi per- 
masalahan tersebut. Kerusakan oksidatif antara lain menyebabkan terbentuknya flavour yang tidak enak, stabilitas umur simpan turun dan penurunan sifat sensoris (Velasco et al. 2003). Mikroenkapsulasi dapat memberikan solusi atas permasalahan tersebut. Mikroenkapsulasi merupakan teknik untuk melindungi bahan inti (core) yang semula berbentuk cair menjadi bentuk padatan sehingga mudah dalam penanganannya serta dapat melindungi bahan inti dari kehilangan flavour (Soottitantawat et al. 2003; Gharsallaoui et al. 2007; Marcuzzo et al. 2010; dan Nedovic et al. 2011). Dalam proses mikroenkapsulasi, hal yang perlu diperhatikan adalah jenis penyalut yang digunakan. Gum arab, maltodekstrin, dan whey merupakan penyalut yang sering digunakan. Maltodekstrin sering digunakan karena memiliki sifat sebagai penyalut yang baik karena kemampuannya dalam membentuk emulsi dan viskositasnya yang rendah (Khrisnan et al. 2005 dan Laohasongkram et al. 2011). Selain itu, maltodeksrin ini banyak digunakan karena mudah ditemukan, mudah dalam penanganan proses (Moore et al. 2005), dapat mengalami dispersi yang cepat, memiliki kelarutan yang tinggi, mampu membentuk matrik kemungkinan terjadinya pencoklatan rendah, mampu menghambat kristalisasi, memiliki daya ikat kuat, viskositas rendah dan stabil pada emulsi minyak dalam air (Dickinson, 2003). Gharsallaoui et al. (2007) menambahkan bahwa maltodekstrin mempunyai kemampuan yang baik dalam menghambat reaksi oksidasi sehingga mikrokapsul yang dihasilkan mempunyai umur simpan yang lebih baik daripada menggunakan gum arab.

Penelitian terdahulu tentang mikroenkapsulasi pada minyak dari famili Zingiberaceae dengan menggunakan pengering semprot dan maltodekstrin sebagai penyalut pernah dilakukan oleh Nurlaili (2011) dan Efendi (2000). Nurlaili meneliti tentang karakterisasi minyak atsiri jahe dan oleoresin ampas jahe dengan menggunakan penyalut maltodekstrin. Efendi (2000) membandingkan proses mikroenkapsulasi minyak atsiri jahe dengan menggunakan penyalut gum arab dan maltodekstrin. Hasilnya menunjukkan bahwa mikroenkaspsulasi dapat berjalan baik dengan maltodekstrin sebagai penyalutnya. Hal ini tentu tergantung dari suhu, konsentrasi bahan inti, dan konsentrasi penyalut. Sejauh ini, belum dijumpai penelitian tentang penggunaan maltodekstrin sebagai bahan penyalut minyak atsiri lengkuas. Selain itu, penelitian ini perlu dilakukan karena hingga saat ini pengolahan lengkuas menjadi bentuk bubuk dengan metode mikroenkapsulasi masih belum dikembangkan. Oleh karena itu, penelitian ini dilakukan dengan tujuan untuk menentukan sifat mikrokapsul (nilai aw, minyak atisiri di permukaan, minyak atsiri terperangkap, dan total volatil, serta senyawa utama penyusun) minyak lengkuas yang dienkapsulasi menggunakan maltodekstrin.

\section{BAHAN DAN METODE}

\section{Bahan}

Bahan yang digunakan dalam penelitian ini adalah minyak atisiri lengkuas (Alpinia galanga) yang berasal dari PT. Indesso Aroma (Bogor, Indonesia). Minyak atsiri tersebut dikemas dalam botol alumunium. Bahan penyalut yang digunakan adalah maltodekstrin dari Brataco (Semarang, Indonesia). SigmaAldrich (Steinheim, Germany).

\section{Pembuatan mikroemulsi}

Pembuatan mikroemulsi dilakukan dengan menggunakan metoda Efendi (2000). Secara garis besarnya adalah sebanyak $160 \mathrm{~g}$ maltodekstrin dan $160 \mathrm{~mL}$ aquades (1:1) kemudian ditambah dengan minyak atsiri dihomogenisasi dengan menggunakan Turrax homogenizer (IKA-T 50 Basic, Artisan Tech Group, Champaign, USA) selama 2 menit pada kecepatan $11.500 \mathrm{rpm}$. Perbandingan antara minyak atsiri dan maltodekstrin adalah variasi 1:8; 1:10, dan 1:12.

\section{Mikroenkapsulasi minyak atsiri lengkuas}

Mikroenkapsulasi dilakukan dengan menggunakan sebuah pengering semprot (Spray Dryer, SD-Basic Lab Plant, West Yorkshire, UK). Laju umpan sebesar $15 \mathrm{~mL} /$ menit dengan suhu inlet dan outlet masing-masing sebesar 120 dan $80^{\circ} \mathrm{C}$

\section{Analisis}

Terhadap produk kemudian dilakukan beberapa analisis yaitu: kadar air (metoda gravimetri, AOAC, 1990), aw menggunakan aw meter (Pawkit-Aqualab, Pullman, USA), minyak atsiri di permukaan dan minyak atsiri terperangkap (Yuliani et al. 2007), Total minyak atsiri (Shaikh et al. 2006), efisiensi mikroenkapsulasi, dan profil senyawa volatil (Soottitantawat et al. 2003). Semua data yang disajikan dalam penelitian ini diperoleh dari pengulangan sebanyak tiga kali, dan dianalisis secara statistik dengan menggunakan program SPSS 2007.

\section{Minyak atsiri di permukaan mikrokapsul (Yuliani et al. 2007)}

Sebanyak $0.5 \mathrm{~g}$ (a) mikrokapsul dalam erlenmeyer diekstrak dengan $6.7 \mathrm{~mL}$ heksana (Sigma-Aldrich), kemudian dikocok dan disaring menggunakan kertas Whatman No. 1. Ekstrak dimasukkan ke dalam labu evaporator yang telah diketahui beratnya (b). Pencucian diulang dengan $3.3 \mathrm{~mL}$ heksana sebanyak 3 kali. Kombinasi ekstrak diuapkan pelarutnya menggunakan rotary vacuum evaporator pada suhu $40^{\circ} \mathrm{C}$. Residu ditimbang sebagai minyak atsiri pada permukaan mikrokapsul (c):

$$
\% \text { Minyak di permukaan }=\frac{c-b}{a} \times 100 \%
$$

\section{Minyak atsiri terperangkap (Yuliani et al. 2007)}

Sebanyak $10 \mathrm{mg}$ mikrokapsul dilarutkan dalam $0.5 \mathrm{~mL}$ etanol (Sigma-Aldrich) kemudian disaring dengan menggunakan kertas Whatman No. 1. Residu yang tertinggal pada kertas saring kemudian dilarutkan dalam kloroform (SigmaAldrich). Penambahan kloroform terus dilakukan hingga volumenya mencapai $10 \mathrm{~mL}$ (menggunakan labu ukur $10 \mathrm{~mL}$ ). Larutan tersebut kemudian di sonikasi selama 5 menit dan disaring kembali hingga diperoleh filtrat. Filtrat kemudian dimasukkan ke dalam cawan yang telah diketahui beratnya dan dipanaskan ke dalam oven $105^{\circ} \mathrm{C}$ selama 30 menit. Berat minyak atisiri terperangkap didapatkan dari hasil timbangan setelah pemanasan berlangsung. 


\section{Total minyak atsiri (Shaikh et al. 2006)}

Sebanyak $0.25 \mathrm{~g}$ mikrokapsul ditambahkan $15 \mathrm{~mL}$ etil eter (Sigma-Aldrich) dan $5 \mathrm{~mL}$ aquades kemudian dihomogenisasi sedikitnya 1 menit pada 3.000 putaran/menit. Selanjutnya ditambahkan $5 \mathrm{~mL}$ etanol dan kemudian dihomogeniser selama 1 menit pada 3.000 putaran/menit. Hasil campuran kemudian ditampung dalam corong pemisah I. Cawan homogeniser dibilas dengan $5 \mathrm{~mL}$ aquades dan dimasukkan ke dalam corong pemisah I. Larutan dalam corong pemisah I dibiarkan selama 1 menit, sampai jelas terpisah antara lapisan eter dan air. Lapisan bagian bawah (yang larut air) dipisahkan dalam sebuah beker gelas kemudian ditambahkan $10 \mathrm{~mL}$ etil eter dan $5 \mathrm{~mL}$ etanol yang selanjutnya dikocok. Campuran ditampung ke dalam corong pemisah II, selanjutnya beker gelas dibilas dengan $5 \mathrm{~mL}$ aquades. Setelah itu, di dalam corong pemisah dibiarkan beberapa saat sampai terpisah antara bagian eter (bagian atas) dan air (bagian bawah). Bagian yang larut air $\left(R_{w}\right)$ ditampung dalam cawan yang telah diketahui beratnya. Larutan yang larut eter $\left(R_{e}\right)$ digabungkan dengan yang berada pada corong pemisah I, kemudian ditampung dalam cawan yang telah diketahui beratnya. Cawan kemudian diuapkan dalam ruang asam dan selanjutnya dikeringkan dalam oven pada suhu $105^{\circ} \mathrm{C}$ selama 4 jam. Perhitungan TV dan NV menggunakan persamaan berikut.

1. $\% N V$ (Non Volatile) $=R_{e} / S \times 100$, dimana $S$ adalah berat sampel dan $R_{e}$ adalah berat residu larut eter.

2. $\% E E(E t i l$ Eter $)=100+W-\left(R_{w} / S \times 100\right)$, dimana $S$ adalah berat sampel, $R_{w}$ adalah berat residu larut air.

3. $\%$ TV (Nolatile Total) $=\%$ EE $-\%$ NV

\section{Efisiensi mikroenkapsulasi}

Penentuan efisiensi mikroenkapsulasi dapat diketahui dengan menggunakan persamaan berikut.

\section{Efisiensi= Minyak terperangkap / Volatil total}

\section{Profil Minyak atsiri sesudah mikroenkapsulasi (Soottitantawat et al. 2003 dengan modifikasi)}

Sebanyak $0.1 \mathrm{~g}$ dari mikrokapsul ditambah $4 \mathrm{~mL}$ aquades dan $2 \mathrm{~mL}$ heksana lalu divortex selama 1 menit, kemudian dipanaskan dengan blok pemanas (Advantec TR-20) pada suhu $90^{\circ} \mathrm{C}$ selama 30 menit. Setelah dingin, disentrifugasi $3.000 \mathrm{rpm}$ selama 10 menit. Fraksi heksana dikeringkan terlebih dengan menggunakan $\mathrm{Na}_{2} \mathrm{SO}_{4}$ anhidrous sebelum dilakukan analisa dengan menggunakan GC-MS. GC-MS (QP2010 SHIMADZU, Shimadzu, Kyoto, Japan) yang digunakan dilengkapi dengan kolom kapiler Rastek Stabilwax@-DA (Rastek, Bellefonte, USA) dengan panjang $30 \mathrm{~m}$ dan diameter $0.25 \mathrm{~mm}$. Suhu injeksi yang digunakan adalah $215^{\circ} \mathrm{C}$. Kondisi suhu kolom adalah $60^{\circ} \mathrm{C}$ ditahan selama 5 menit, kemudian suhu dinaikkan hingga $215^{\circ} \mathrm{C}$ dengan kecepatan $5^{\circ} \mathrm{C} /$ menit dan ditahan selama 10 menit. Gas Helium digunakan sebagai gas pembawa. Rasio split injeksi 1:43, dan pemisahan menggunakan energi sebesar 70 Ev. Interpretasi senyawa dilakukan dengan membandingkan spektra masa dan waktu retensi senyawa volatile dengan bank data spektra masa yang dimiliki GC-MS (GC-MS data base Solution Ver.2.3) atau dengan bank data spektra masa yang terdapat pada pustaka (NIST Chemistry WebBook, http:/l webbook.nist.gov/chemistry/). Konsentrasi kualitatif senyawa volatil dinyatakan sebagai persen relatif, diperoleh dengan membandingkan luas area setiap senyawa dengan luas area total.

\section{HASIL DAN PEMBAHASAN}

\section{Kadar air}

Kadar air merupakan parameter penting yang berhubungan dengan stabilitas produk selama penyimpanan (Yuliani et al. 2007). Data hasil penelitian tentang pengaruh rasio antara minyak atsiri lengkuas dan maltodekstrin terhadap kadar air produk disajikan pada Gambar 1.

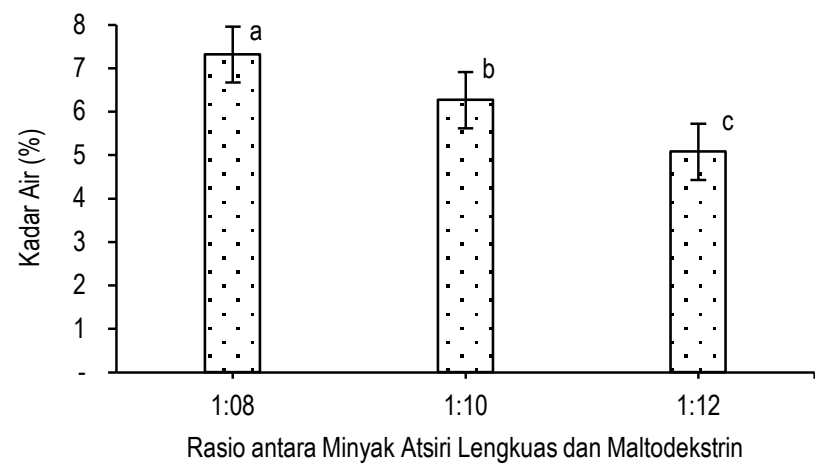

Gambar 1. Pengaruh rasio antara minyak atsiri lengkuas dengan maltodekstrin terhadap kadar air produk. Huruf yang berbeda pada setiap faktor perlakuan menunjukkan perbedaan nyata pada taraf uji $p=0.05$

Berdasarkan Gambar 1, didapatkan hasil kadar air pada rasio $1: 8$ adalah $7.31 \%$, rasio $1: 10$ sebesar $6.27 \%$, dan rasio $1: 12$ sebesar $5.08 \%$. Kadar air tersebut berkisar antara $5-7 \%$, dan menunjukkan perbedaan yang nyata diantara perlakuan rasio yang diberikan $(p<0.05)$. Kadar air ini masih relatif tinggi karena menurut Reineccius (2004) dalam Yuliani et al. (2007), tipikal kadar air produk yang dihasilkan dari pengering semprot adalah $2-6 \%$. Kadar air yang relatif tinggi pada produk yang dihasilkan diduga dapat disebabkan karena viskositas dari emulsi yang kurang tinggi sehingga kadar air yang dihasilkan masih diatas tipikal kadar air produk (Masters, 1984).

Berdasarkan Gambar 1 juga dapat dikatakan bahwa bahwa semakin tinggi konsentrasi bahan inti yang terdapat pada emulsi, kadar air dari produk yang dihasilkan juga semakin tinggi. Adanya konsentrasi bahan inti yang tinggi, akan menyebabkan titik didihnya menjadi tinggi pula sehingga dengan suhu pengeringan yang sama akan dihasilkan produk dengan kadar air lebih tinggi.

\section{Aktivitas air (aw)}

Aktivivitas air (aw) adalah jumlah air bebas yang terdapat dalam suatu bahan dan merupakan salah satu faktor penting yang harus diperhatikan karena berpengaruh terhadap kualitas produk pangan. Nilai $a_{w}$ produk enkapsulasi disajikan pada Gambar 2 . 


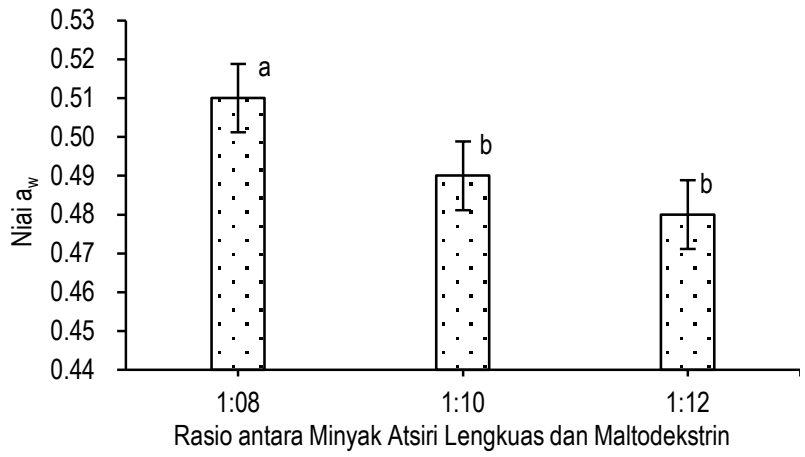

Gambar 2. Pengaruh rasio antara minyak atsiri lengkuas dan maltodekstrin terhadap nilai aktivitas air (aw) produk. Huruf yang berbeda pada setiap faktor perlakuan menunjukkan perbedaan nyata pada taraf uji $p=0.05$

Berdasarkan Gambar 2, didapatkan hasil bahwa rasio 1:8 memiliki aktivitas air (aw) sebesar 0.51 dan berbeda nyata dengan dua perlakuan lainnya, sedangkan rasio 1:10 sebesar 0.49 , dan rasio $1: 12$ sebesar 0.48 , nilai tersebut tidak berbeda nyata diantara keduanya $(p<0.05)$. Berdasarkan hasil tersebut, terlihat bahwa rasio 1:8 memiliki nilai aktivitas air (aw) yang paling tinggi dibandingkan rasio 1:10 dan rasio 1:12. Nilai $a_{w}$ tersebut selaras dengan kadar air produk. Produk dengan dar rasio 1:8, 1:10, dan 1:12 masing-masing sebesar 7.31, 6.27, dan $5.08 \%$. Hal ini menunjukkan bahwa semakin rendah konsentrasi bahan inti yang terdapat dalam emulsi, maka semakin rendah nilai aktivitas air $\left(\mathrm{a}_{\mathrm{w}}\right)$ yang dihasilkan oleh produk. Begitu pula sebaliknya, semakin tinggi konsentrasi bahan inti yang terdapat dalam emulsi, maka semakin tinggi pula nilai aktivitas airnya $\left(\mathrm{aw}_{\mathrm{w}}\right.$. Produk dengan bahan inti tinggi, air yang ada lebih susah diuapkan selama proses pengeringan. Sebagai akibatnya kadar air produk dan nilai $a_{w}$ menjadi lebih tinggi.

\section{Minyak di permukaan}

Persentase minyak di permukaan pada penelitian ini menunjukkan banyaknya minyak yang terdapat pada permukaan luar dinding mikrokapsul. Adanya minyak di permukaan luar mikrokapsul ini tidak dikehendaki karena dapat menyebabkan bahan inti sangat mudah terpapar oleh udara, khususnya oksigen dan uap air, sehingga dapat mempercepat kerusakan produk. Pengaruh rasio antara minyak atsiri lengkuas dan maltodekstrin pada penelitian yang dilakukan disajikan pada Gambar 3.

Berdasarkan Gambar 3, terlihat bahwa semakin tinggi konsentrasi bahan inti yang terdapat dalam emulsi, maka persentase minyak di permukaan yang dihasilkan akan semakin tinggi. Nilai minyak di permukaan yang rendah menunjukkan bahwa banyak bahan inti yang terperangkap. Pada Gambar 3, ditunjukkan bahwa persentase minyak di permukaan paling tinggi terdapat pada rasio 1:8 yaitu dengan persentase minyak di permukaan sebesar $1.53 \%$ yang diikuti dengan rasio 1:10 sebesar $1.22 \%$ dan rasio $1: 12$ sebesar $0.93 \%$. Berdasarkan hasil pengujian statistik, nilai persentase minyak di permukaan berbeda nyata satu sama lainnya $(p<0.05)$. Semakin tinggi persentase minyak di permukaan, produk akan rentan me- ngalami kerusakan dan akan dapat menurunkan kualitas bahan aktif selama distribusi maupun penyimpanan.

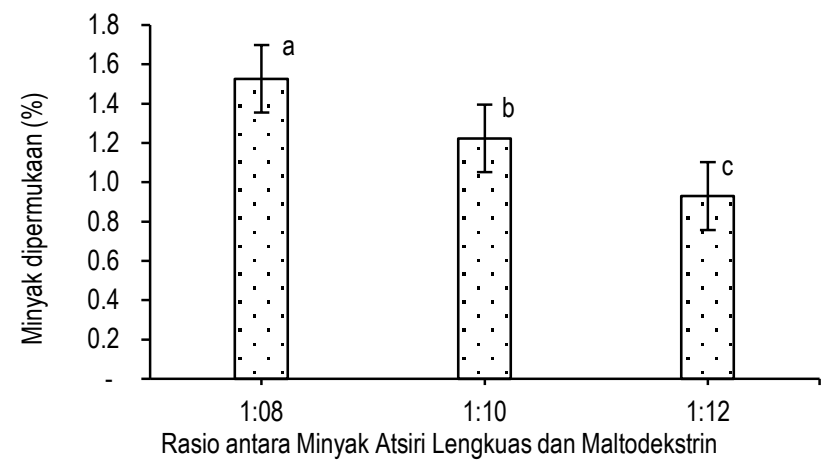

Gambar 3. Pengaruh rasio antara minyak atsiri lengkuas dan maltofekstrin terhadap minyak di permukaan/produk. Huruf yang berbeda pada setiap faktor perlakuan menunjukkan perbedaan nyata pada taraf uji $p=0.05$

Semakin tinggi konsentrasi bahan inti pada emulsi, maka semakin tinggi pula minyak di permukaan yang dihasilkan. Hal ini dikarenakan semakin tinggi konsentrasi bahan inti, maka viskositas yang dihasilkan dalam emulsi campuran menjadi rendah. Sugindro et al. (2008) mengatakan bahwa adanya viskositas emulsi yang rendah selama proses pengering semprot berlangsung, akan membuat lapisan kulit (crust) yang terbentuk tidak begitu kuat sehingga bahan inti menjadi kurang terlindungi. Selain itu adanya viskositas yang rendah menyebabkan proses pengeringan berlangsung lama dan jumlah minyak atsiri yang terperangkap dalam mikrokapsul sangat dipengaruhi oleh kecepatan pengeringan dan pembentukan lapisan kulit. Jumlah minyak atsiri yang terperangkap dapat meningkat jika pembentukan kulit berlangsung cepat. Oleh karena jumlah minyak atsiri yang terperangkap meningkat, maka jumlah minyak yang terdapat pada permukaan mikrokapsul menjadi berkurang sehingga nilai minyak di permukaan yang dihasilkan rendah. Selain itu, Tonon et al. (2011) menambahkan bahwa adanya viskositas yang tinggi menyebabkan lapisan kulit yang terbentuk kuat sehingga dapat mengurangi migrasi minyak menuju permukaan luar mikrokapsul.

\section{Minyak terperangkap}

Minyak terperangkap merupakan banyaknya minyak atsiri yang terdapat di dalam mikrokapsul. Produk dengan minyak terperangkap tinggi menunjukkan bahwa minyak yang dapat terlindungi oleh matriks penyalut banyak. Pengaruh rasio antara minyak atsiri lengkuas dan maltodekstrin terhadap minyak terperangkap disajikan pada Gambar 4.

Urutan persentase minyak terperangkap mikrokapsul pada tiap rasio dari yang paling tinggi adalah rasio $1: 12$ sebesar $22.96 \%$, rasio $1: 10$ sebesar $22.78 \%$, dan rasio $1: 8$ sebesar $22.51 \%$. Berdasarkan data tersebut, terlihat bahwa rasio $1: 8$ memiliki persentase minyak terperangkap terendah, meskipun demikian ketiga variasi perlakuan tidak menunjukkan nilai yang berbeda nyata $(p<0.05)$. Adanya persentase minyak terperangkap yang rendah menunjukkan bahwa jumlah minyak 
atsiri (bahan inti) yang dapat dilindungi oleh penyalut juga rendah.

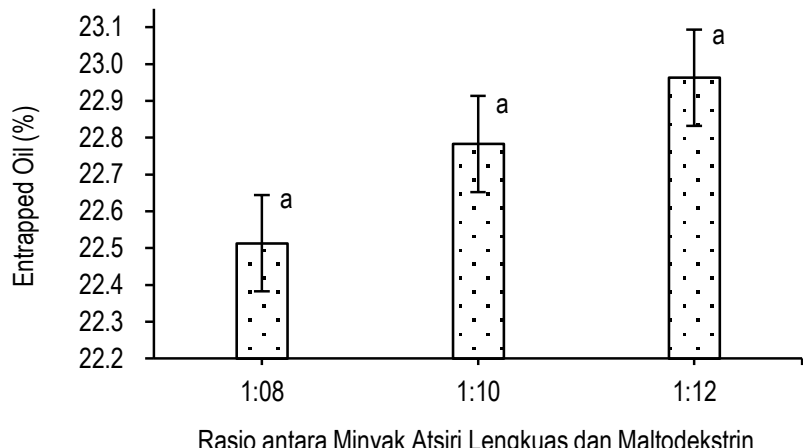

Gambar 4. Pengaruh rasio antara minyak atsiri lengkuas dan maltofekstrin terhadap minyak terperangkap produk. Huruf yang berbeda pada setiap faktor perlakuan menunjukkan perbedaan nyata pada taraf uji $p=0.05$

Pada rasio 1:8 dihasilkan persentase minyak terperangkap yang rendah karena tingginya konsentrasi bahan inti yang terdapat dalam emulsi sehingga akan dihasilkan viskostias yang rendah. Adanya viskositas emulsi yang rendah selama proses pengering semprot berlangsung, akan membuat lapisan kulit yang terbentuk tidak begitu kuat sehingga bahan inti menjadi kurang terlindungi. Selain itu adanya viskositas yang rendah menyebabkan proses pengeringan berlangsung lama dan jumlah bahan inti yang terperangkap dalam mikrokapsul sangat dipengaruhi oleh kecepatan pengeringan dan pembentukan lapisan kulit. Jumlah bahan inti yang terperangkap dapat meningkat jika pembentukan kulit berlangsung cepat. Pada sisi lain, adanya viskositas yang tinggi menyebabkan lapisan kulit yang terbentuk kuat sehingga dapat mengurangi migrasi minyak menuju permukaan luar mikrokapsul. Akibatnya, dihasilkan nilai minyak terperangkap yang tinggi pada emulsi berviskositas tinggi.

\section{Volatil total}

Kadar volatil total dalam penelitian ini adalah jumlah total dari seluruh minyak atisiri yang terdapat pada mikrokapsul, baik yang terdapat di dalam maupun yang menempel di permukaan mikrokapsul. Hasil dari penelitian yang dilakukan disajikan pada Gambar 5.

Gambar 5 menunjukkan pengaruh rasio antara minyak atsir lengkuas dan maltodekstrin terhadap volatil total produk yang dihasilkan. Berdasarkan hasil tersebut, terlihat bahwa pada rasio 1:8 dihasilkan persentase volatil total sebesar $43.66 \%$, rasio 1:10 memiliki persentase volatil total sebesar $42.22 \%$, dan rasio 1:12 memiliki persentase volatil total sebesar $41.44 \%$. Hasil pengujian statistik, persen volatil total rasio $1: 8$ menunjukkan hanya berbeda dengan nilai dari rasio 1:12, sedangkan antara rasio 1:10 dan rasio 1:12 tidak saling berbeda nyata $(p<0.05)$. Berdasarkan hasil tersebut, dapat dikatakan bahwa semakin tinggi konsentrasi bahan inti yang terdapat pada emulsi akan menghasilkan persentase volatil total yang makin tinggi. Tingginya volatil total pada rasio 1:8 dapat disebabkan oleh tingginya kadar minyak di permukaan yang terdapat pada mikrokapsul sehingga berpengaruh pada nilai volatil total yang dihasilkan.

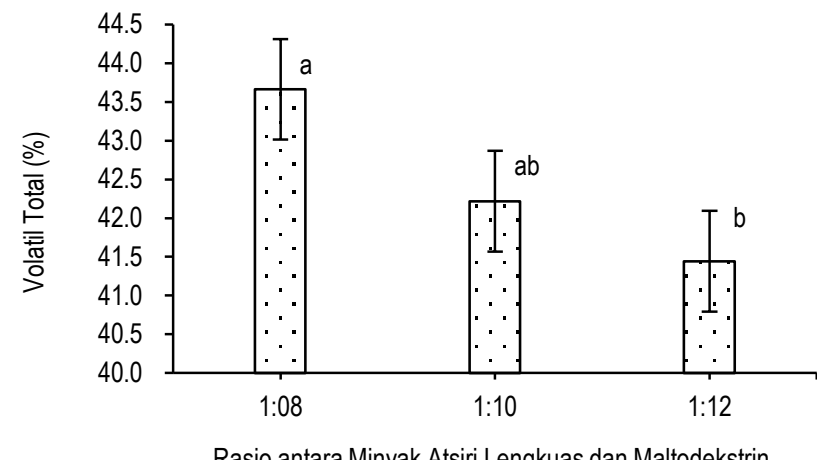

Gambar 5. Pengaruh rasio antara minyak atsiri lengkuas dan maltofekstrin terhadap volatile total produk. Huruf yang berbeda pada setiap faktor perlakuan menunjukkan perbedaan nyata pada taraf uji $p=0.05$

Bila dihubungkan antara data volatil total yang dihasilkan dengan minyak di permukaan dan minyak terperangkap pada Gambar 3 dan 4, maka terlihat adanya ketidaksesuaian. Seharusnya jumlah antara minyak terperangkap dan minyak di permukaan sama atau mendekati volatil total atau dapat dikatakan bahwa nilai volatil total merupakan penjumlahan dari minyak terperangkap dengan minyak di permukaan. Akan tetapi pada data, didapatkan bahwa selisih antara penjumlahan minyak terperangkap dan minyak dipermukaan terhadap volatil total mencapai sekitar 50\%. Hal ini diduga karena adanya perbedaan polaritas pada jenis pelarut yang digunakan ketika dilakukan analisa.

Pada analisa penentuan minyak terperangkap, pelarut yang digunakan adalah etanol dan pada analisa volatil total digunakan pelarut etil eter. Berdasarkan nilai dari nilai polaritas pelarut didapatkan bahwa nilai polaritas dari etil eter sebesar 2.8 dan etanol sebesar 5.2. Berdasarkan nilai polaritas tersebut, terlihat bahwa nilai polaritas dari pelarut etanol lebih tinggi dari etil eter. Adanya nilai polaritas yang tinggi menyebabkan kemampuan pelarut untuk berikatan dengan senyawa volatil menjadi lebih rendah. Akibatnya, nilai minyak terperangkap yang didapat lebih rendah, sehingga berpengaruh terhadap hasil volatil total yang dihasilkan. Selain itu, pada analisis ini digunakan metode untuk menganalisis persentase volatil total pada oleoresin. Hal tersebut tidak sesuai untuk menentukan persentase volatil total pada minyak atsiri karena pada metode ini digunakan suhu pengeringan sebesar $105^{\circ} \mathrm{C}$ untuk menghilangkan pelarut. Jika hal ini dilakukan untuk analisis minyak atsiri, maka banyak senyawa volatil yang hilang ketika pengeringan berlangsung dan akan mempengaruhi nilai volatil total yang dihasilkan.

\section{Efisiensi mikroenkapsulasi}

Penghitungan efisiensi mikroenkapsulasi digunakan untuk mengetahui tingkat keberhasilan proses mikroenkapsulasi. Efisiensi yang dimaksud dalam penelitian ini adalah perbandingan antara minyak terparangkap dengan volatil total. Semakin tinggi efisiensi mikroenkapsulasi berarti semakin baik pula kemampuan penyalut dalam melindungi bahan intinya. 
Pengaruh rasio antara minyak atsiri lengkuas dan maltodekstrin terhadap efisiensi mikroenkapsulasi yang dihasilkan dapat dilihat pada Gambar 6. Berdasarkan Gambar 6, rasio 1:8 menghasilkan efisiensi mikroenkapsulasi sebesar $51.56 \%$, sedangkan rasio 1:10 dan 1:12 menghasilkan efisiensi mikroenkapsulasi sebesar 53.96 dan $55.40 \%$. Hasil pengujian statistik menjukkan bahwa nilai tersebut saling berbeda nyata $(p<0.05)$. Berdasarkan data tersebut, terlihat bahwa rasio 1:8 mempunyai nilai efisiensi yang paling rendah. Adanya nilai efisiensi yang rendah ini menunjukkan bahwa jumlah minyak yang dapat dikapsulkan sedikit.

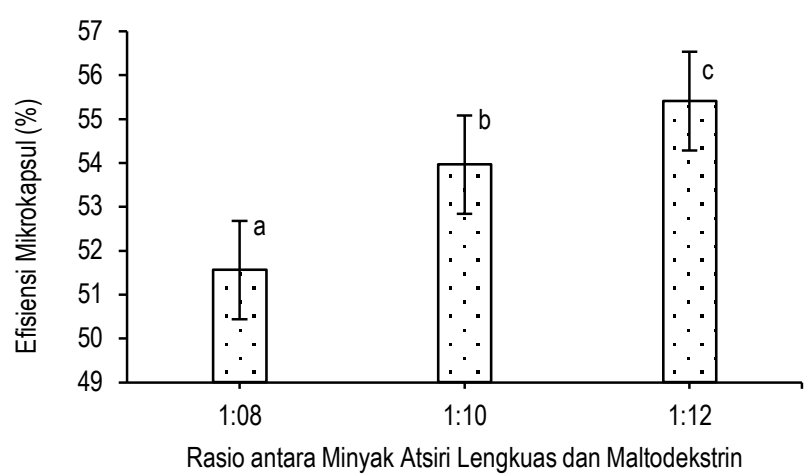

Gambar 6. Pengaruh rasio antara minyak atsiri lengkuas dan maltodekstrin terhadap mikroenkapsulasi. Huruf yang berbeda pada setiap faktor perlakuan menunjukkan perbedaan nyata pada taraf uji $p=0.05$

Penelitian terdahulu (Yanuwar et al. 2007) juga menunjukkan efisiensi mikroenkapsulasi yang berhubungan dengan konsentrasi penyalut dan konsentrasi bahan inti. Pada penelitian tersebut, dilakukan variasi proporsi minyak buah merah terhadap efisiensi mikroenkapsulasi yang dihasilkan. Berdasarkan penelitian tersebut didapatkan hasil bahwa mikrokapsul dengan bahan inti minyak buah merah sebesar $20 \%$ menghasilkan efisiensi sebesar $74.84 \%$, dan kemudian pada bahan inti 30 dan $40 \%$ dihasilkan efisiensi sebesar 70.16 dan $55.79 \%$.

Young et al. (1993) dalam Yanuwar et al. (2007) menjelaskan bahwa efisiensi mikroenkapsulasi semakin menurun dengan peningkatan bahan intinya. Frascareli et al. (2012) juga menyatakan bahwa salah satu faktor yang mempengaruhi efisiensi mikroenkapsulasi adalah konsentrasi bahan inti. Efisiensi akan meningkat dengan semakin rendahnya kosentrasi bahan inti. Hasil yang sama juga didapatkan dari Ahn et al. (2007) yang membahas tentang mikroenkapsulasi minyak bunga matahari dengan menggunakan penyalut isolat protein susu dan dekstrin. Rasio 1:12 memiliki efisiensi yang tinggi karena konsentrasi bahan inti yang terdapat dalam emulsi rendah. Adanya konsentrasi bahan inti yang rendah menyebabkan viskositas yang dihasilkan tinggi. Bangs dan Reineccius (1982) mengatakan bahwa semakin tingginya viskositas, retensi yang dihasilkan tinggi sehingga kemampuan untuk melindungi bahan inti lebih baik.

Profil minyak atsiri sebelum dan sesudah mikroenkapsulasi

Salah satu tujuan mikroenkapsulasi adalah melindungi bahan aktif dari kerusakan. Pada analisis ini, dilakukan peng- identifikasian bahan aktif sebelum proses mikroenkapsulasi dan setelah proses mikroenkapsulasi yang dapat dilihat pada Tabel 1. Komponen-komponen volatil utama minyak atsiri lengkuas pada umumnya adalah 1.8-sineol (17.59\%), $\beta$-pinen (12.85\%), $\alpha$-pinen $(13.23 \%)$, dan metil sinamat $(33.03 \%)$ dan beberapa komponen senyawa lain dengan kosentrasi rendah. Kelima senyawa utama tersebut tetap menjadi senyawa yang dominan pada produk enkapsulasi.

Terdapat tiga senyawa yang mengalami kenaikan relatif setelah proses enkapsulasi, yakni kampor, metil sinamat, dan $\alpha$-terpineol. Nilai persen relatif ketiga senyawa tersebut menunjukkan tidak berbeda nyata diantara perlakuan yang diberikan $(p<0.05)$. Sedangkan apabila dibandingkan dengan minyak lengkuas yang tidak dienkapsulasi, hanya senyawa kampor yang rasionya menunjukkan tidak berbeda nyata. Senyawa metil sinamat merupakan senyawa yang konsentrasinya meningkat secara drastis pada produk enkapsulasi, hampir mencapai dua kali konsentrasi pada produk minyak yang belum dienkapsulasi. Senyawa tersebut termasuk dalam kategori senyawa ester, senyawa yang mudah mengalami kerusakan. Keberadaan senyawa metil sinamat sebagai senyawa utama pada produk enkapsulasi menandakan bahwa proses enskapsulasi mampu melindungi minyak lengkuas selama proses. Sedangkan senyawa kampor, dan $\alpha$-terpineol hanya sedikit mengalami peningkatan, bahkan dapat dikatakan relatif tetap. Keberadaan tiga senyawa utama lainnya (1.8-sineol, $\alpha$ pinen, dan $\beta$-pinen) justru mengalami penurunan secara relatif pada produk enkapsulasinya. Meskipun demikian rasio ketiga senyawa tersebut tidak berbeda nyata diantara variasi perakuan, maupun dengan dengan minyak atsirinya. Besarnya penurunan ketiga senyawa tersebut berkisar antara 6-26\%. Pada hasil GC-MS, juga dijumpai beberapa senyawa volatil minor hilang setelah proses mikroenkapsulasi antara lain kampen dan terpinen-4-ol.

Penyebab berkurangnya komponen volatil pada mikroenkapsulasi selain dipengaruhi oleh sifat senyawa juga dipengaruhi ukuran globula emulsi yang dihasilkan. Ukuran globula emulsi yang besar dipengaruhi oleh banyaknya bahan inti (minyak atisiri lengkuas) yang terdapat pada emulsi. Semakin banyak bahan inti yang ditambahkan, maka ukuran globula emulsi yang dihasilkan akan makin tinggi (Tonon et al. 2011). Soottitantawat et al. (2003) meneliti mengenai kehilangan senyawa limonen selama mikroenkapsulasi dengan menggunakan penyalut gum arab dan maltodekstrin. Kehilangan senyawa limonen tersebut terjadi akibat meningkatnya ukuran globula emulsi. Pada kondisi tersebut senyawa volatil yang terperangkap dalam system emulsi banyak mengalami kerusakan.

Senyawa-senyawa volatil mempunyai deskripsi aroma masing-masing. Adanya kombinasi antara senyawa-senyawa tersebut akan membuat timbulnya flavour yang khas. Pada hasil penelitian yang dilakuan, dapat diketahui beberapa deskripsi aroma dari komponen-komponen volatil yang dihasilkan, contohnya metil sinamat yang merupakan komponen paling dominan memiliki deskripsi aroma yang mirip rempah-rempah (spicy), manis, dan spesifik kayu manis (Azeez, 2008, dan Burdock, 2010); 1.8-sineol memiliki deskripsi aroma fresh (menyegarkan), cool (memberikan respon dingin), dan 
medicinal (aroma seperti rempah-rempah) (Chida et al. 2006 dan Burdock, 2010) banyak dijumpai pada ekstrak tanaman Eucalyptus globules (Rodríguez et al. 2006); sedangkan untuk a-pinen dan $\beta$-pinen dapat memberikan odor yang menyerupai pala dan cengkeh (Jirovetz et al. 2003, dan Vijlanen et al. 2011). Beberapa senyawa volatil minor seperti kampor memiliki deskripsi aroma yang berupa herbal dan terpinen-4-ol memilik deskripsi aroma yang berupa sweet (aroma manis seperti buah) (Sawamura et al. 2004).

Tabel 1. Perubahan komponen senyawa volatil utama minyak atsiri sebelum dan sesudah mikroenkapsulasi

\begin{tabular}{|c|c|c|c|c|}
\hline \multirow{2}{*}{$\begin{array}{c}\text { Senyawa } \\
\text { Volatil }\end{array}$} & \multicolumn{4}{|c|}{ Persentase Relatif (\%) } \\
\hline & $\begin{array}{c}\text { Minyak } \\
\text { Lengkuas }\end{array}$ & $\begin{array}{c}\text { Rasio*) } \\
(1: 8)\end{array}$ & $\begin{array}{c}\text { Rasio*) } \\
(1: 10)\end{array}$ & $\begin{array}{c}\text { Rasio*) } \\
(1: 12)\end{array}$ \\
\hline Naik: & & & & \\
\hline Kampor & $\begin{array}{l}1.00 \pm \\
\left.0.11^{a^{* *}}\right)\end{array}$ & $\begin{array}{c}1.04 \pm \\
17^{\mathrm{a}}\end{array}$ & $\begin{array}{l}1.05 \pm \\
0.22^{\mathrm{a}}\end{array}$ & $\begin{array}{l}1.04 \pm \\
0.19 \mathrm{a}\end{array}$ \\
\hline Metil sinamat & $\begin{array}{c}33.03 \pm \\
4.98^{\mathrm{a}}\end{array}$ & $\begin{array}{c}61.01 \pm \\
5.00^{\mathrm{b}}\end{array}$ & $\begin{array}{c}57.72 \pm \\
2.31^{b}\end{array}$ & $\begin{array}{c}58.23 \pm \\
2.53^{\mathrm{b}}\end{array}$ \\
\hline a-terpineol & $\begin{array}{l}1.55 \pm \\
0.10^{a}\end{array}$ & $\begin{array}{c}2.11 \pm \\
0.13^{b}\end{array}$ & $\begin{array}{l}1.82 \pm \\
0.03^{b}\end{array}$ & $\begin{array}{l}1.69 \pm \\
0.20^{a b}\end{array}$ \\
\hline Turun & & & & \\
\hline a-pinen & $\begin{array}{c}13.23 \pm \\
1.95^{\mathrm{a}}\end{array}$ & $\begin{array}{l}9.15 \pm \\
2.04^{\mathrm{ab}}\end{array}$ & $\begin{array}{l}9.64 \pm \\
1.71 \mathrm{ab}\end{array}$ & $\begin{array}{c}10.52 \pm \\
2.38^{\mathrm{ab}}\end{array}$ \\
\hline$\beta$-pinen & $\begin{array}{c}12.85 \pm \\
2.59^{a}\end{array}$ & $\begin{array}{l}9.44 \pm \\
2.37 a\end{array}$ & $\begin{array}{l}9.65 \pm \\
2.57^{a}\end{array}$ & $\begin{array}{c}10.23 \pm \\
3.24 \mathrm{a}\end{array}$ \\
\hline 1-pelandren & $\begin{array}{l}1.58 \pm \\
0.45^{\mathrm{a}}\end{array}$ & - & $\begin{array}{l}0.93 \pm \\
0.48^{b}\end{array}$ & - \\
\hline Limonen & $\begin{array}{l}1.69 \pm \\
0.80^{a}\end{array}$ & - & $\begin{array}{l}1.12 \pm \\
0.45^{\mathrm{a}}\end{array}$ & $\begin{array}{l}1.01 \pm \\
0.20^{a}\end{array}$ \\
\hline 1.8-sineol & $\begin{array}{c}17.59 \pm \\
1.72^{\mathrm{a}}\end{array}$ & $\begin{array}{c}16.69 \pm \\
0.18^{a}\end{array}$ & $\begin{array}{c}15.99 \pm \\
3.12^{\mathrm{a}}\end{array}$ & $\begin{array}{c}16.75 \pm \\
1.77^{a}\end{array}$ \\
\hline $\mathrm{p}$-cimen & $\begin{array}{l}2.19 \pm \\
0.20^{a}\end{array}$ & $\begin{array}{l}1.60 \pm \\
0.09^{b}\end{array}$ & $\begin{array}{l}1.73^{ \pm} \\
0.13^{b}\end{array}$ & $\begin{array}{l}1.56 \pm \\
0.30^{\mathrm{b}}\end{array}$ \\
\hline$\beta$-selinen & $\begin{array}{l}0.40 \pm \\
0.10^{\mathrm{a}}\end{array}$ & - & $\begin{array}{l}0.35 \pm \\
0.05^{\mathrm{a}}\end{array}$ & - \\
\hline
\end{tabular}

Senyawa volatil yang terdapat pada produk enkapsulasi dengan rasio 1:10 menunjukkan paling lengkap diantara dua rasio lainnya (Tabel 1). Produk dari rasio 1:10 mempunyai kemiripan odor dengan minyak lengkuas yang paling tinggi, disusul rasio 1:12 dan 1:8. Akan tetapi, konsumen relatif lebih menyukai produk dengan rasio 1:8 dengan alasan aroma lebih kuat tercium. Penilaian tersebut selaras dengan nilai minyak di permukaannya. Produk dari rasio 1:8 mempunyai minyak dipermukaan paling tinggi (Gambar 3). Produk dengan minyak dipermukaan tinggi menandakan banyak senyawa volatil terdapat dipermukaan produk. Keuntungannya adalah senyawa volatil lebih banyak diterima oleh organ pencium pada saat dilakukan pengujian sensoris. Adapaun kelemahannya adalah produk lebih mudah kehilangan atau kerusakan senyawa volatil pada saat distribusi dan perdagangan. Selain itu produk hasil rasio 1:8 mempunyai kadar air dan nilai aw paling tinggi (Gambar 1 dan 2). Produk dengan kadar air dan nilai aw tinggi mempunyai kelemahan yakni senyawa volatil yang terikat lebih mudah lepas ke lingkungannya (Chin et al. 2010). Produk dari rasio 1:8 juga mempunyai kelemahan lain yakni jumlah minyak yang terperangkap dan efisiensi paling kecil (Gambar 4 dan 6) artinya minyak yang berhasil dilindungi oleh maltodekstrin paling kecil. Meskipun antara produk dari rasio 1:10 dan 1:12 terdapat kemiripan, akan tetapi kelengkapan seyawa volatil pada produk dari rasio 1:10 paling lengkap. Oleh karena itu, untuk keperluan jangka panjang (distribusi dan perdagangan) dan kelengkapan profil senyawa volatil produk dari rasio 1:10 lebih direkomendasikan sebagai rasio terbaik.

\section{KESIMPULAN}

Maltodesktrin mampu melindungai senyawa utama pada minyak lengkuas selama proses enkapsulasi. Untuk keperluan penggunaan produk dalam jangka panjang tidak disarankan enkapulasi minyak lengkuas dan maltodekstrin dengan rasio 1:8, tetapi 1:10.

\section{DAFTAR PUSTAKA}

Ahn JH, Kim YP, Lee YM, Seo EM, Lee KW, Kim HS. 2007. Optimization of microencapsulation of seed oil by response surface methodology. Food Chem 107: 98-105. DOI: 10.1016/j.foodchem.2007.07.067.

[AOAC] Association of Official Analytical Chemists. 1990. Official Methods of Analysis of The Association of Official Analytical Chemist, Fifteenth Edition. 69-70. Arlington, Washington.

Azeez S. 2008. Vanilla. Dalam Parthasarathy, VA, Champaka, B, Zachariah, TJ (Eds). Chemistry of Spices. P. 286-319. CAB International. Oxfordshire. UK.

Bangs WE, Reineccius GA. 1982. Influence of dryer infeed matrices on the retention of volatile flavor compounds during spray drying. J Food Sci 47: 254-259. DOI: 10.1111/ j.13652621.1982.tb11072.x.

[BPS] Badan Pusat Statistik. 2012. Statistik Indonesia 2012. http://bps.go.id/index/php [1 Januari 2013].

Burdock GA. 2010. Fenaroli's Handbook of Flavor Ingridiens. $6^{\text {th }}$ Edition. P: $677-678,1243-1244$. CRC Press. Boca RatonFlorida.

Calvo P, Castano AL, Lozano M, Gonzales-Gomez D. 2012. Influence of the microencapsulation on the quality paramaters and shelf-life of extra-virgin olive oil encapsulated in the presence of $\mathrm{BHT}$ and different capsule wall component. Food Res Int 45: 256-261. DOI: 10.1016/j. foodres.2011.10.036.

Chida M, Yamashita K, Izumiya Y, Watanabe K, Tamura H. 2006. Aroma impact compounds in three citrus oils: crossmatching test and correspondence analysis approch. J Food Sci 71: S54-S58. DOI: 10.1111/j.1365-2621.2006.tb12406.x.

Chin ST, Nazimah SAH, Quek SY, Mand YBC, Rahman RA, Hashim MD. 2010. Effect of thermal processing and storage on the flour stability of spray-dried durian powder. LWTFood Sci Technol 43: 856-861. DOI: 10.1016/.Iwt.2010. 01.001.

Chudiwal AK, Jain DP, Somani RS. 2010. Alpinia galanga wildan overview on phyto-pharmacological properties. Indian $\mathrm{J}$ Nat Prod Res 1: 143-149. 
Dickinson E. 2003. Hydrocolloids at interfaces and the influence on the properties of dispersed systems. Food Hydrocolloid 17: 25-39. DOI: 10.1016/S0268-005X(01)00120-5.

Efendi E. 2000. Mikroenkapsulasi Minyak Atsiri Jahe dengan Campuran Gum Arab - Maltodekstrin dan Variasi Suhu Inlet Spray Dryer [Thesis]. Program Studi Teknologi Hasil Perkebunan UGM.

Frascareli EC, Silva VM, Tonon RV, Hubinger MD. 2012. Effect of process conditions on the microencapsulation of coffee oil by spray drying. Food Bioprod Process 90: 413-424. DOI: 10.1016/j.fbp.2011.12.002.

Gharsallaoui A, Roudaut G, Chambin O, Voilley A, Saurel R. 2007. Applications of spray-drying in microencapsulation of food ingredients: an overview. Food Res Int 40: 1107-1121. DOI: 10.1016/j.foodres.2007.07.004.

Hamid AA, Aiyelaagbe OO, Usman LA. 2011. Essential oils: its medicinal and pharmacological uses. Int J Curr Res 3: 8698.

Jirovetz L, Buchbaurer G, Pottachola M, Kalathil N. 2003. Analysis of the essential oils of the leaves, stems, rhizomes and roots of the medicinal plant Alpinia galanga from Southern India. Acta Pharm 53: 73-81.

Kaushik D, Yadav J, Kaushik P, Sacher D, Rani R. 2011. Current pharmacological and phytochemical studies of the plant Alpinia galanga. J Chinese Integrative Medicine 9: 1061-1065. DOI: 10.3736/jcim20111004.

Khrisnan S, Bhosale R, Singhal RS. 2005. Microencapsulation of cardamom oleoresin: evaluation of blends of gum arabic maltodextrin and a modified starch as wall materials. Carbohyd Polym 61: 95-102. DOI: 10.1016/j.carbpol. 2005.02.020.

Laohasongkram K, Mahamaktudsanee T, Chaiwanichsiri S. 2011. Microencapsulation of macadamia oil by spray drying. Procedia Food Sci 1: 1660-1665. DOI: 10.1016/j.profoo. 2011.09.245.

Marcuzzo E, Sensidoni A, Debeaufort F, Voilley A. 2010 Encapsulation of aroma compounds in biopolymeric emulsion based edible film to controle flavour release. Carbohyd Polym 80: 984-988. DOI: 10.1016/j. carbpol.2010.01.016.

Masters K. 1984. Spray Drying Handbook: Drying of Droplets/Sprays. 298-341. John Wiley and Sons. New York.

Moore GRP, do Canto LR, Amante ER, Soldi V. 2005. Cassava and corn starch in maltodextrin production. Quim Nova 28: 596-600. DOI: 10.1590/S0100-40422005000400008.

Nurlaili FA. 2011. Karakterisasi Mikrokapsul Minyak Atsiri Jahe dan Oleoresin Ampas Jahe (Zingiber officinale var. Rubrum) dengan Penyalut Maltodekstrin. [Tesis]. Program Studi Teknologi Hasil Perkebunan, UGM: Yogyakarta.

Petrovic GM, Stojanovic GS, Radulovic NS. 2010. Encapsulation of cinnamon oil in $\beta$-cyclodextrin. J Med Plants Res 14: 1382-1390. DOI: 10.5897/JMPR10.146.

Rodríguez P, Sierra W, Rodríguez S, Menéndez P. 2006. Biotransformation of 1.8-cineole, the main product of Eucalyptus oils. Electron J Biotechn 9: 232-236. DOI: 10.2225/vol9-issue3-fulltext-28.

Sawamura M, Tu NTM, Onishi Y, Ogawa E, Choi HS. 2004. Characteristic odor components of Citrus reticulata blanco (Ponkan) cold- pressed oil. Biosci Biotechnol Biochem 68: 1690-1697. DOl: 10.1271/bbb.68.1690.

Shaikh J, Bhosale R, Singhal R. 2006. Microencapsulation of black pepper oleroresin. Food Chem 94: 105-110. DOI: 10.1016/j.foodchem.2004.10.056.

Soottitantawat A, Yoshii H, Futura T, Ohkawara M, Linko P. 2003. Microencapsulation by spray drying: influence of emulsion size on the retention of volatile compounds. J Food Sci 68: 2256-2262. DOI: 10.1111/j.1365-2621.2003. tb05756.x.

Sugindro, Mardliyati E, Djajadisastra J. 2008. Pembuatan dan mikroenkapsulasi ekstrak etanol biji jinten hitam pahit (Nigella sativa Linn.). Majalah IImu Kefarmasian 5: 57-66.

Syamsir E. 2011. Penanganan bumbu dan rempah. Kulinologi Indonesia (7). http://ilmupangan.blogspot.com/2011/08 /penanganan-bumbu-dan-rempah.html [19 Juni 2013].

Tonon RV, Grosso CRF, Hubinger MD. 2011. Influence of emulsion composition and inlet air temperature on the microencapsulation of flaxseed oil by spray drying. Food Res Int 44: 282-289. DOI: 10.1016/j.foodres.2010.10.018.

Yanuwar W, Widjanarko SB, Wahono T. 2007. Karakteristik dan stabilitas antioksidan mikrokapsul minyak buah merah (Pandanus conoideus Lam) dengan bahan penyalut berbasis protein. J Tek Pertanian 8: 127-135.

Yuliani S, Desmawarni NH, Yuliani SS. 2007. Pengaruh laju alir umpan dan suhu inlet spray drying pada karakteristik mikrokapsul oleoresin jahe. J Pascapanen 4: 18-26.

Yuharmen Y, Eryanti Y, Nurbalatif. 2002. Uji aktivitas antimikrobia minyak atsiri dan ekstrak metanol lengkuas (Alpinia galanga). J Nature Indonesia 4: 178-183.

Velasco J, Dobarganes C, Marques-Ruiz G. 2003. Variables affecting lipid oxidation in dried miencrocapsulated oils. Grasas Aceities 54: 304-314. DOI: 10.3989/gya.2003. v54.i3.246. 